\title{
Approaching Sustainability of Construction and Demolition Waste Using Zero Waste Concept
}

\author{
Sally M. Elgizawy ${ }^{{ }^{*}}$, Salah M. El-Haggar ${ }^{2}$, Khaled Nassar ${ }^{1}$ \\ ${ }^{1}$ The Construction Engineering Department, The American University in Cairo, Cairo, Egypt \\ ${ }^{2}$ The Mechanical Engineering Department, The American University in Cairo, Cairo, Egypt \\ Email: sallygizawy@aucegypt.edu, elhaggar@aucegypt.edu,knassar@aucegypt.edu
}

Received 20 January 2016; accepted 6 March 2016; published 10 March 2016

Copyright (C) 2016 by authors and Scientific Research Publishing Inc.

This work is licensed under the Creative Commons Attribution International License (CC BY).

http://creativecommons.org/licenses/by/4.0/

(c) (i) Open Access

\begin{abstract}
Construction and demolition waste constitutes a huge part of the solid waste management system and is continuous on the rise because of the booming housing and building industry worldwide. Construction and demolition waste is not clear in its definition; it differs according to the location and type of the project which make it complicated to find a generic solution to construction and demolition waste management problems. A comprehensive list of construction and demolition waste stream was formulated and used in the course of this study. A thorough literature review was conducted to study the end life of each of the components of the construction and demolition waste stream and their reuse or recycling option. The conventional treatment of construction and demolition waste which is dumping them in landfills was presented and its negative impact on the environmental and socio-economic aspects and on sustainability highlighted making recycling the most viable option. The study aims at having a clearer picture of C \& D waste classification methods, its components and their end of life treatment and evaluating them through the lenses of zero waste management. Zero waste is a way that promotes changing lifestyle and, ideologies to reach the ultimate goal of sustainable development through eliminating waste and having materials that circulate in closed loops. Applying zero waste concept to manage construction and demolition waste would be a great improvement in waste management as it promotes the reuse of resources, preserves the environment and is considered a step towards a sustainable environment.
\end{abstract}

\section{Keywords}

Sustainable Solid Waste Management, C \& D Waste, Recycling, Zero Waste Concept

\footnotetext{
${ }^{*}$ Corresponding author.
}

How to cite this paper: Elgizawy, S.M., El-Haggar, S.M. and Nassar, K. (2016) Approaching Sustainability of Construction and Demolition Waste Using Zero Waste Concept. Low Carbon Economy, 7, 1-11. 


\section{Introduction}

This construction and demolition waste is not new worldwide and has started booming as population increased and accordingly their housing needs increased. As time progressed, and as a result of the fast urbanization and the construction boom that happened almost worldwide during the 1990s, the amount of C \& D waste generated which was traditionally sent to landfills started increasing to uncontrollable levels. Given the limited landfill space, and the increasing costs of effective environmental protection of landfill, it was obvious that action to reuse or recycle C \& D waste is becoming critical, especially that natural resources are also depleting causing a real threat to all countries. The construction industry worldwide uses more raw materials (about $3000 \times 10^{6}$ ton/year, almost $50 \%$ by weight) than any other industry [1] leading to a clearly unsustainable industry. Approximately one-third of materials dumped in landfills in the US by volume are construction and demolition waste [2]. In 1996, the C \& D waste in Austria, Denmark, Germany and The Netherlands was estimated to be about 300, more than 500, about 2600 and about $900 \mathrm{~kg} / \mathrm{cap}$, respectively as stated in [3] and this has been continuous on the rise ever since.

Studies conducted by Lauritzen and Hahn in 1992 estimated the total generation rate of building and construction waste generated in many developed countries as 500 - $1000 \mathrm{~kg}$ per capita per year [4].

C \& D waste represents one of the biggest shares of the solid wastes in almost all countries; it is also a consumer of a tremendous amount of natural resource and energy as well as emitter of lots of greenhouse gases which make it hence imperative to reduce the rate of $C \& D$ waste generation and maximize their reuse and recycling as an approach towards more sustainable C \& D waste management. Following the zero waste concepts particularly on construction and demolition waste is a great progress towards sustainability as all waste materials are intended to become resources for other activities or processes hence minimizing the negative impacts of land filling. According to the definition adopted by the Zero Waste International Alliance on August 12, 2009, zero waste concept was defined as "designing and managing products and processes to systematically avoid and eliminate the volume and toxicity of waste and materials, conserve and recover all resources, and not burn or bury them" [5]. Zero waste concepts are based on the belief that waste is a potential resource with a good value to benefit from, rather than a problem to deal with. It encourages the shift from one-way or linear resource cycle of use and disposal to a closed or circular flow of material. The zero waste approach is particularly important in industrial and building processes as it promotes the full use of industrial or construction inputs in final products or modifying them to better fit other industries or processes without generating waste. This has an immense benefit of eliminating waste to land, air or water causing a positive impact on sustainability. From the environmental point of view, zero waste strategies help reduce the public health risks and greenhouse gas emissions related to landfills as well as the energy consumed in the production by decreasing the need to extract and refine virgin materials. Nowadays, wastes are managed in an uneconomical manner. Landfills and incinerators which are the traditional end destination for waste require money to be constructed, maintained and operated. Recovered resources, following the closed loops concept allow for more jobs and less waste which benefit greatly any country on many levels including the economical level

\section{Construction and Demolition Waste Stream}

The Environmental Protection Agency (EPA) in the US defines C \& D waste as "waste that is generated from the construction, renovation, repair, and demolition of structures such as residential and commercial buildings, roads, and bridges”. C \& D waste comprises mainly concrete, asphalt, masonry and wood products as well as metals, plastics, insulation, and paper and cardboard [6].

Tchobanoglous et al. (1977) define construction and demolition wastes as: "Wastes from razed buildings and other structures are classified as demolition wastes. Wastes from the construction, remodeling, and repairing of individual residences, commercial buildings, and other structures are classified as construction wastes” [7]. The generation of construction waste can be attributed to six main stages or sources such as design, procurement, and handling of materials, operation and residual sources [8]. Demolition wastes are a heterogeneous combination of various building materials such as aggregate, wood, paper, metal, and glass that are in most cases contaminated with paints, adhesives and wall coverings. These types of wastes results from the demolishing of existing structures which are done intentionally like in renovation and remodeling works or unintentionally due to natural catastrophes such as earthquakes, floods, hurricanes, etc. The components of demolition wastes and its quantities depend primarily on the type and age of the structure being demolished as well as the materials used for its construction and the demolition technique followed [9]. 
Construction and demolition waste definition is not absolute and varies according to the location and type of the project which makes it complicated to find a generic solution to C \& D waste management problem.

Based on a thorough literature review, it was identified that wastes from infrastructure and road works are sometimes included as construction and demolition waste and other times they are separately accounted for. In a trial to formulate a generic definition of construction and demolition waste, the following description will be used in the course of this paper:

C \& D waste is the waste generated during the construction process of a building or that resulted from its demolition including:

- Waste resulting from the demolition of buildings

- Waste resulting from the construction of buildings

- Waste resulting from the renovation of buildings

\section{Classification of C \& D Waste}

C \& D waste is considered one of the largest amounts of waste in the solid waste stream, and represents a real threat to all countries. Its composition is not unique and depends on the techniques of construction, type of building, country and many other factors. The diversity in building techniques has led to a difficulty in having one specific list of C \& D waste that can be applicable to all projects in all countries however there have been many trials throughout history to categorize C \& D waste.

Spivey (1974) is considered one of the first few people interested to categorize construction wastes. He classified the most common components of wastes in construction and demolition sites in relation to their source [10]:

- Demolition waste (i.e., concrete, brick, etc.)

- Packaging waste (i.e., paper, cardboard, plastic, etc.)

- Wood waste

- Concrete waste

- Asphalt

- Garbage and sanitary waste

- Scrap-metal waste

- Rubber and glass

- Pesticides and non-pesticide containers.

Other efforts to identify the components of construction and demolition waste that have been carried out include Symonds group Ltd. (1999) who also confirmed that the composition of construction and demolition waste can vary enormously from site to site and divided them into three types of waste, originating from [11]:

- New construction

- Renovation

- Demolition

Renovation waste and demolition wastes are very similar in composition. Construction waste is generally caused by damaged materials and excess quantity ordering. Figure 1 illustrates the division of the C \& D waste into demolition waste, renovation waste and construction waste across the EU countries.

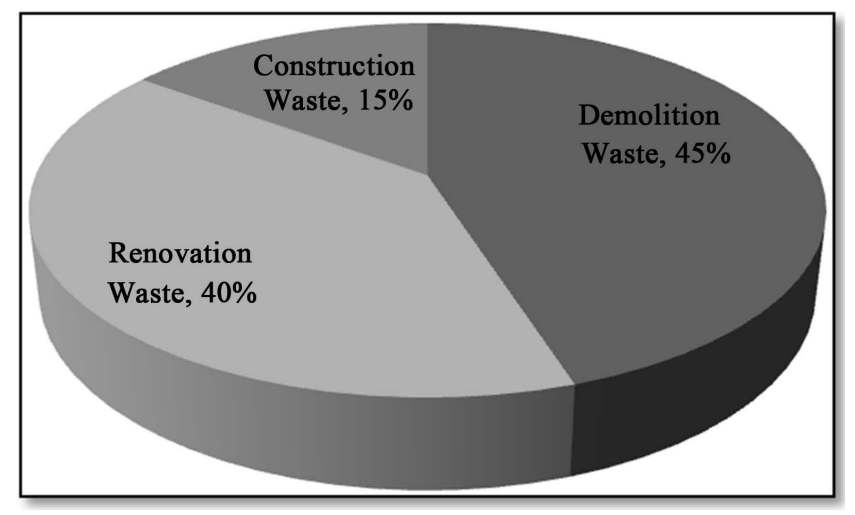

Figure 1. C \& D waste in the EU countries [11]. 
In one of the journal articles by Papadopoulos et al. C \& D, waste refers to a wide spectrum of materials categorized according to their origin [12]:

- Excavation materials: it includes soil, sand, gravel, rocks, clay and all materials resulting from excavation works. They are found in all types of construction and infrastructure work.

- Road works and maintenance: it includes asphalt and other pavement materials such as sand and gravel as well as metal and other material waste coming from road works.

- Demolition materials or debris: it consists of soil, gravel, concrete, bricks, sand and stone, etc. They are heterogeneous in nature and their composition varies depending on many factors like location, age, shape, use and size of the building.

- Waste from worksite: includes almost all materials like wood, plastic, paper, glass, metal, pigments. It results from the operation of workers on site.

Skoyles early on in 1976 presented a different approach of classifying construction and demolition waste into Direct and indirect waste, where the direct waste is the material which needs to be replaced (defect in the material itself) and indirect waste which is attributed to [13] [14]:

- Substitution waste: when materials are used not as described in the specification.

- Production waste: represents materials used in excess of those indicated in the bill of quantities, because of onsite requirements.

- Negligence waste: some materials are used in excess of the amount originally required due to the contractor's own negligence and workers inaccuracy.

Table 1 summarizes the classification of $C \&$ D waste as found in the literature and highlights the idea that there is no one set of $\mathrm{C} \& \mathrm{D}$ waste components that is common to all projects.

Based on the listing in Table 1, it is worth mentioning that there is no single way of classifying C \& D waste, however the most common one is classification by source or origin which is seen to be beneficial because it reveals a lot of information about the nature of the waste. For example demolition waste is known to be contaminated with other materials, like paint or adhesives whereas excavation materials waste is basically sand and aggregates. This facilitates their handling, separation and recycling.

\section{Recycling of C \& D Waste}

The variety in the composition of construction and demolition waste due to different practices in different countries and difference in the type of project itself as well as factors of location and design makes it intricate to ac-

Table 1. A brief summary of different ways of classifying C \& D waste.

\begin{tabular}{|c|c|c|}
\hline \multirow{2}{*}{ Author } & \multicolumn{2}{|r|}{ Different ways of classifying C \& D waste } \\
\hline & Type of classification & Description \\
\hline Spivey 1974 & By source/origin & $\begin{array}{l}\text { 1. Demolition waste (like concrete, brick, wallboard, plaster) } \\
\text { 2. Packaging materials (like paper, cardboard, plastic) } \\
\text { 3. Wood } \\
\text { 4. Waste concrete and asphalt } \\
\text { 5. Garbage and sanitary waste } \\
\text { 6. Scrap metal } \\
\text { 7. Rubber, and glass } \\
\text { 8. Pesticides and non-pesticide containers. }\end{array}$ \\
\hline Symonds group Ltd. (1999) & General types of waste & $\begin{array}{l}\text { 1. New construction. } \\
\text { 2. Renovation } \\
\text { 3. Demolition }\end{array}$ \\
\hline Papadopoulos et al. (2003) & By source/origin & $\begin{array}{l}\text { 1. Waste from excavation. } \\
\text { 2. Waste from road planning and maintenance materials } \\
\text { 3. Waste from demolition materials } \\
\text { 4. Worksite waste materials }\end{array}$ \\
\hline Skoyle (1976 a, b) & Direct and indirect waste & $\begin{array}{l}\text { 1. Direct waste: complete loss of a material } \\
\text { (inevitable waste involving the necessary replacement of a material) } \\
\text { 2. Indirect waste: loss of materials value, to the contractor. } \\
\text { These are further subdivided into substitution waste, } \\
\text { production waste and negligence waste }\end{array}$ \\
\hline
\end{tabular}


curately formulate a list of the components of C \& D waste arising for all types of construction worldwide. It is possible however, to identify a number of key components, which can be expected to occur to some extent in the waste stream in the majority of construction projects, such as:

- Concrete

- Wood

- Metal ferrous (Steel) and metal non-ferrous (Copper, Aluminum)

- Masonry (bricks and mortar)

- Plastic (PVC pipes, plastic films for packaging, wall coverings )

- Glass

- Ceramic tiles

- Insulation material (mineral wool insulation, styrofoam)

- Drywall/gypsum board

- Filling material (gravel, sand and soil)

- Paper and cardboard

- Marble and granite

Many of the components of the C \& D waste stream have been subject to lots of research concerning their possible recycling techniques, as well as their reuse options. Concrete for example is commonly recycled as a supplement to natural aggregates such as crushed stone, sand and gravel and this has been approved by the American Society for Testing and Materials (ASTM) and American Association of State Highway and Transportation Officials (AASHTO) as a source of aggregate into new concrete [15]. Wood waste can be used as soil amendment, compost or as an ingredient to manufacture pulp and paper products, it can also be grinded into product suitable for on-site use as mulching, or as more desirable boiler fuel [7]. Masonry bricks are also likely to replace natural aggregates, such as sand and gravel, which are always used in large amounts.

Based on the literature review and the author's interpretation, the $C \& D$ waste materials can be ranked as per their ease of recycling in a range of scores from 1 - 5 with score of 1 being the most difficult to recycle and 5 the easiest as shown in Table 2.

It is clear from Table 2 that ferrous metal, non-ferrous metal and papers or cardboards are the easiest materials to be recycled, and they undergo efficient recycling techniques and produce materials of similar value which

Table 2. Different waste materials and their ranking based on their ease of recycling.

\begin{tabular}{ccc}
\hline & Ease of Recycling of Different Waste Materials & \\
\hline Waste Material & Score \\
\hline Concrete & 4 \\
Wood & 3 & \\
Ferrous Metal & 5 & 5 \\
Non-Ferrous Metal & 3 \\
Masonry & 3 \\
Plastic & 3 \\
Glass & 4 \\
Ceramic Tiles & 4 \\
Mineral Wool & 2 \\
Styrofoam & 2 \\
Drywall & 2 \\
Filling Material & 3 \\
Paper & 5 \\
Marble & 3 \\
\hline
\end{tabular}


is considered up-cycling of the waste. Concrete, glass and ceramic tiles come next on the list because recycling is not yet optimized and there are still problems facing their recycling in terms of technique, efficiency and cost effectiveness. Masonry, filling materials and marble present a problem because of the big amount of powder or fine materials produced when crushed which is not in most cases recyclable yet. Gypsum board, Styrofoam and mineral wool insulation although have high potential to be used in other processes, their recycling techniques are not yet fully developed in terms of cost effectiveness and quality of recycled products. These components are presented in details in this section and the challenges of their recycling discussed.

\subsection{Insulation (Styrofoam/Polystyrene and Mineral Fibers)}

One of the many types of Building insulation is thermal insulation. It helps reduce surplus heat loss or gain and accordingly decrease the energy needed for heating and cooling by additional systems. Building insulation materials vary in composition (natural or synthetic fibers) as well as in form (spray, panels, etc.) among the various building insulation materials are Styrofoam and mineral fibers.

\subsubsection{Styrofoam}

One Styrofoam is usually used in packaging purposes for electrical appliances and consist a huge part of solid waste as well because of its extensive use in disposable items like plates and cups, moreover because of its superior insulating properties, expanded polystyrene foam, often referred to as Styrofoam is used as building insulation material in walls, floors and roofs in residential and commercial buildings. As is the case with all organic compounds, polystyrene burns to give carbon dioxide and water vapor. It is a light weight component however is quit bulky to transport. Styrofoam is a petroleum-based plastic which does not biodegrade by time and is very dangerous when burnt so it presents a real problem. Some researches are conducted to accommodate the Styrofoam in its present form in other materials manufacturing. Jong-Jin Kim, tried in 1998 to form a new type of drainage system which replaces gravel, with pieces of polystyrene, which would otherwise be dumped into landfills. This new type of product can be used in foundations works, in drainage fields and parking lots [16]. This new product might not be very cost effective in its use when compared to gravel which has very low cost, for that reason continuing research is needed to come up with alternative uses or recycling techniques for used polystyrene. Polystyrene is rarely recycled because it is usually not cost effective as the start-up costs for a polystyrene recycling plant are enormous and the pay-off, is still uncertain. Moreover Polystyrene is bulky, it's difficult and expensive to transport and cannot even be used for products that contact food because of health concerns.

\subsubsection{Mineral Wool/Rockwool}

The total volume of C \& D waste generated in the EU countries in 2010 was estimated to be 857 million tones including hazardous waste and debris, and the estimated waste from mineral wool in 2010 was 2.3 million tones [17]. Accordingly, $0.2 \%$ of all C \& D waste generated is mineral wool. Mineral wool is widely used in insulation in buildings as heat insulation, fire protection, and noise insulation. Mineral Wool is an inorganic product manufactured using stone/rock (volcanic rock, basalt or dolomite) in addition to blast furnace or steel slag which constitutes $97 \%$ of mineral wool production [18]. The binders used in mineral wool production are typically urea-phenol-formaldehyde-based solutions [19]. The amount of binder used in mineral wool is only around $1 \%$ $2 \%$ consisting of phenol and formaldehyde which are known to have serious negative health effects.

According to figures derived from the Department for Communities and Local Government in the UK, the volume of insulation products installed in buildings each year in the UK is approximately 14 million cubic meters [18]. The market size for insulation generally is expected to increase as more awareness into the conservation of energy arises. Figure 2 shows the breakdown of the insulation market by value.

Mineral wool is a waste that is being considered as un-recyclable. The main problem of mineral wool waste lies within its contaminating effect. Waste mineral fiber is exceptionally difficult to recycle back into mineral wool product due to the presence of the organic coatings which would contaminate air if heated.

Current recycling and disposal options for waste mineral fiber are its use as a raw material in the manufacture of mineral fiber ceiling tiles; or landfilling.

Possible alternative solutions for the recycling of mineral wool waste include for example the utilization of mineral wool waste in cement-based composites [20] composite ceramics [21] or wood fiber composites [22]. A 


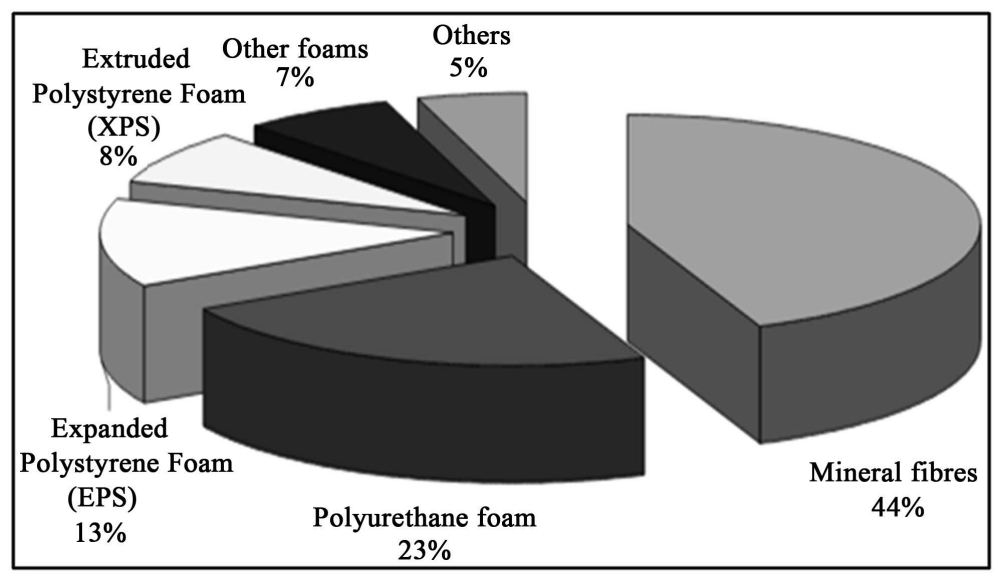

Figure 2. Breakdown of the insulation market by value [18].

new solution for the recycling of mineral wool waste could be the utilization of the waste as filler in wood polymer composites. Its problem is that if the interfacial adhesion between the mineral wool fibers and polypropylene matrix can be improved, many of the mechanical properties could be improved as well [22]. This could be achieved via the addition of a different coupling agent or surface treatment of the mineral wool fibers. The result would be a wood plastic composite with good mechanical and moisture resistance properties. If satisfactory mechanical properties can be met, recycled mineral wool could prove to be an environmentally and economically viable alternative to commercial filler materials.

\subsection{Drywall/Gypsum Boards}

Drywall has become one of the major components in modern construction, yet it is one of the less likely components to be recycled. Gypsum drywall, often referred to as gypsum wallboard, plasterboard, Gypboard or sheet rock, replaced old gypsum plaster as the major interior wall surface because of its ease of installation and its fire resistant properties. Gypsum drywall is composed of 90 percent gypsum and 10 percent paper facing and backing. Gypsum is calcium sulfate dehydrate $\left(\mathrm{CaSO}_{4} \cdot 2 \mathrm{H}_{2} \mathrm{O}\right)$. Composition studies on construction debris find that gypsum wallboard makes up 5\% to $25 \%$ of the waste stream [23]. In the United States, the National Association of Home Builders Research Centre has estimated that gypsum waste constitutes $27 \%$ of all residential construction waste [24]. Typical estimate for drywall generation from construction activities is one pound of drywall per square foot of construction [25].

Drywall recycling businesses have been most successful in recycling scrap drywall from new construction activities because of the ease of separation and the lack of contamination with other materials. However there are still few end-markets that allow for certain tolerance in contaminated or mixed gypsum waste.

Several possible proposed markets for recycling gypsum drywall are shown in Table 3.

Use of gypsum waste directly in manufacturing is not feasible because each end use product has different tolerance to paper and contamination of the waste to be used. Recycled gypsum to be used for making new drywall for example has to be obtained from manufacturing sites or construction sites so as not to be contaminated with paint or other $\mathrm{C} \& \mathrm{D}$ debris. The problem of construction or manufacturing new drywall from drywall waste however is mainly due to the paper facing and backing in drywall which should be removed first as it decreases the fire resistance of drywall. This process increases the cost on the manufacturer in relation to the price of virgin gypsum which is cheap. The typical gypsum content in Portland cement ranges from 5\% to 10\% [26]. The materials feed system at the cement plant must be pure gypsum. In addition to the problem of soil contamination, paper also should be carefully removed from recycled drywall as there is not much tolerance (only $1 \%$ 2\% paper content) in this end market for paper contamination. A very recent research conducted at The American University in Cairo (AUC) in 2014, aimed to study the possibility of recycling waste gypsum boards for producing new drywalls and non-load bearing gypsum bricks [27]. This was designed using construction materials and certain chemical additives. After extensive experimental work, it was concluded that the flexural strength of gypsum boards conducted using Portland cement and raw gypsum as binders failed to meet the minimum 
Table 3. Summary of major markets for recovered gypsum wallboard [26].

\begin{tabular}{cc}
\hline Market & Use \\
\hline Manufacturing Processes & Manufacture of new drywall \\
Manufacture of Portland cement \\
Manufacture of new construction materials \\
Pand Application Markets & Putrients (calcium and sulfur) \\
& Improving soil structure \\
& Reclamation of sodic soils \\
& Correction of subsoil acidity \\
& Plant disease prevention \\
& Reducing phosphorous leaching from manure-loaded soils \\
Other Uses & Animal bedding \\
& Compost \\
& Bulking and drying agent \\
& Absorbent for greases \\
& Settlement of dirt and clay partider in water \\
A material for road base construction \\
An ingredient in flea powder and similar products
\end{tabular}

strength limit. The effect of using eight different chemicals for recycling waste gypsum boards was investigated and only Zinc Sulfate was shown to increase the flexural strength of processed gypsum board.

The main problem hindering full recycling of drywall is the low and unpredictable quality of drywall waste as a result of contamination with other wastes. For that reason, enhancing the quality of gypsum board waste ready to be processed is the key issue for effective recycling. Extensive research and experimental work should be focused on completely removing the paper adhered to the drywall and using chemicals or additives to improve the quality of recycled drywall. This area needs further research and investigations to reach to the best additive to be used to enhance the physical properties of the end product. Virgin gypsum on the other hand is not expensive whereas its cost of recovery is significantly high making drywall recycling not an economically viable alternative at present.

\section{Impact of C \& D Waste}

Most of C \& D wastes are being sent to landfills causing a number of problems both on the environmental and socio-economic aspects and on sustainability.

\subsection{Environmental Impact}

Construction sites are often seen as the cause of a lot of environmental problems such as dust, noise, vibration and pollution of soil and groundwater. The current problems of waste management are mainly the accumulation of wastes in landfills which have limited space resulting in less stringent environmental protection regulations governing land filling operations. Moreover the biodegradation of wastes in the landfills causes a lot of health and environmental problems. When Gypsum drywall becomes wet as a result of reduction in landfill, the sulfate reducing bacteria (SRB) use sulfate electron acceptor to produce $\mathrm{H}_{2} \mathrm{~S}_{4}$ characterized by its offensive odor. According to investigations carried out early on in the US, it was shown that $0.4 \%$ of the construction waste by weight disposed of in landfills is hazardous waste [28]. These hazardous wastes are often generated on construction sites from empty containers which might contain some rests of hazardous wastes like left over paint containers, solvents and adhesives.

\subsection{Socio-Economic Impacts}

A major problem of C \& D wastes is the cross contamination and the general mixing of materials. This mixing of materials makes the reuse or recycling process more complicated and dependent on manual sorting which is labor intensive and time consuming. Also the mixing involves hazardous materials such as asbestos and some heavy metals such as lead, solvents and adhesives which should be strictly separated from the material waste to be reused or recycled. Recycling of C \& D waste is still a costly process in contrast to the cheap price of many of the raw materials used in construction. 


\subsection{Sustainability Impact}

The construction industry is one of the largest and most significant industries, being at the same time the main consumer of natural resources and one of the largest polluters [29]. Within the European community over 40\% of energy and approximately $40 \%$ of the man-made waste are building related [30]. Current construction practices of dumping the wastes in landfills allow for the depletion of natural resources and does not account for energy conservation. The extraction of raw materials as well as the manufacturing process requires a lot of energy which can be minimized through sustainable construction practices

\section{Challenges of C \& D Waste}

The life cycle of a building used to be a one-way process. Building materials were extracted and used in construction and once the building is demolished, the materials were dumped in a landfill or incinerated. The numerous environmental drawbacks of land filling as discussed in the precedent section, in addition to the increased tipping fees for landfills and the scarcity of natural resources led companies to start looking for alternatives based on recycling. What is challenging is that recycling has to be profitable in order to be sustainable and this can be achieved based on the following factors:

- Markets for profitable recycling of C \& D wastes have to be driven and encouraged by the government through incentives, and new legislation and regulation.

- While increased tipping fees in most areas of the country will make recycling more attractive, recycling on the other hand has to be cost effective compared to the price of virgin materials used.

- The proximity of the recycling plants to the sites is also important to reduce cost of transportation of trucking material from the site to the recycling plant.

\section{Conclusion and Recommendations}

It is certain that C \& D waste worldwide with its massive quantity and its adverse effect on the environment like the high risk of environmental pollution and resource depletion is a real threat to mankind. Reusing the C \& D waste from construction is the best end of life alternative based on its environmental impact; unfortunately this is not a common practice in the construction industry currently which involves more complex procedures that do not allow for dismantling and reusing the materials easily and cost effectively. Among the wide and diversified range of construction and demolition waste products, the literature shows special emphasis on recycling major components like concrete and masonry whereas efforts in recycling some other components like gypsum boards, mineral wool insulation and Styrofoam are not yet economically successful. Moreover recycling, which has started long time ago is not sustainable meaning that it might not be cost-effective most of the time and is often considered a down-cycling and not up-cycling of the actual product. For that reason emphasis in this study is on construction and demolition waste management based on zero waste concepts.

Recycling of construction and demolition waste based on the zero waste approach is considered very challenging and needs lots of research and experimental work but at the same time very beneficial as it promotes the closed loop of material circulation which has a huge benefit on the national scale and even worldwide as well. This research has some limitations in covering the impacts of the different building techniques in different countries on the feasibility of full recycling of construction and demolition waste materials. The construction method as well as the deconstruction or dismantling of building components has an impact on its full recycling feasibility. The diversity of the building techniques worldwide impacts greatly the methods of recycling as well as the possible end uses of the recycled materials.

\section{References}

[1] Torgal, F.P. and Labrincha, J.A. (2013) The Future of Construction Materials Research and the Seventh UN Millennium Development Goal: A Few Insights. Journal of Construction and Building Materials, 40, 729-737. http://dx.doi.org/10.1016/j.conbuildmat.2012.11.007

[2] Chun-Li, P., Grosskopf, K.R. and Kibert, C.J. (1994) Construction Waste Management and Recycling Strategies in the United States. Proceedings of the First Conference of CIB TG 16 on Sustainable Construction, Tampa, 689-696.

[3] Brodersen, J., Juul, J. and Jacobsen, H. (2002) Review of Selected Waste Streams: Sewage Sludge, Construction and Demolition Waste, Waste Oils, Waste from Coal-Fired Power Plants and Biodegradable Municipal Waste. European 
Topic Centre on Waste European Environment Agency. http://www.eea.europa.eu/publications/technical_report_2001_69

[4] Lauritzen, E.K. and Hahn, N.J. (1992) Building Waste-Generation and Recycling. ISWA.

[5] ZWIA, Zero Waste International Alliance (2013) ZW Definition. http://zwia.org/standards/zw-definition/

[6] Meyer, K.S. and Walsh, J.J. (1996) Regs among the Ruins. Wastes 360 Recycling Summit, 20-23. http://waste360.com/mag/waste_regs_among_ruins

[7] Tchobanoglous, G., Theisen, H. and Eliassen, R. (1977) Solid Wastes: Engineering Principles and Management Issues. McGraw-Hill Book Co., New York.

[8] Al-Ansary, M.S., El-Haggar, S.M. and Taha, M.A. (2004) Sustainable Guidelines for Managing Demolition Waste in Egypt, 9-11 Nov. 2004, Barcelona, Spain.

[9] El Haggar, S. (2007) Sustainable Industrial Design and Waste Management: Cradle-To-Cradle for Sustainable Development. Academic Press, Cambridge, Massachusetts.

[10] Spivey, D.A. (1974) Environmental and Construction Management Engineers. Journal of Construction, 100, 395-401.

[11] Symonds group Ltd., in association with ARGUS, COWI and PRC Bouwcentrum (1999) Construction and Demolition Waste Management Practices, and Their Economic Impacts. Report to DGXI, European Commission. http://ec.europa.eu/environment/waste/studies/cdw/cdw_chapter1-6.pdf

[12] Papadopoulos, A., Fatta, D., Avramikos, E., Sgourou, E., Moustakas, K., Kourmoussis, F., Mentzis, A. and Loizidou, M. (2003) Generation and Management of Construction and Demolition Waste in Greece-An Existing Challenge. Resources Conservation and Recycling Journal, 40, 81-91. http://dx.doi.org/10.1016/S0921-3449(03)00035-1

[13] Skoyles, E.R. (1976a) Materials Waste-A Misuse of Resources. Batiment International, Building Research and Practice, 4, 232. http://dx.doi.org/10.1080/09613217608550498

[14] Skoyles, E.R. (1976b) Waste of Materials and the Contractors Quantity Surveyor. The Quantity Surveyor, 209-211.

[15] Al-Mutairi, N. and Haque, M. (2003) Strength and Durability of Concrete Made with Crushed Concrete as Coarse Aggregates. Proceedings of the International Symposium on Recycling and Reuse of Waste Materials, Scotland, September 2003, 499-506.

[16] Kim, J.-J. (1998) Sustainable Architecture Module: Qualities, Use, and Examples of Sustainable Building Materials. College of Architecture and Urban Planning, The University of Michigan, Ann Arbor.

[17] Eurostat, European Statistics (2013) Environmental Data Center on Waste-Construction. http://epp.eurostat.ec.europa.eu/portal/page/portal/wa19te/waste_generation_management/generation/construction

[18] Dunster, A. (2007) Characterization of Mineral Wastes, Resources and Processing Technologies-Integrated Waste Management for the Production of Construction Material. Building Technology Group BRE, Department of Environment, Food and Rural Affairs (DEFRA Project), Industry Sector Study: Mineral Wool Insulation, UK.

[19] Balcerowiak, W., Gryta, M. and Kałedkowski, B. (1995) Thermal Stability of Binder for Mineral Wool Insulations. Journal of Thermal Analysis, 43, 299-303. http://dx.doi.org/10.1007/BF02635997

[20] Cheng, A., Lin, W.-T. and Huang, R. (2011) Application of Rock Wool Waste in Cement-Based Composites. Materials \& Design, 32, 636-642. http://dx.doi.org/10.1016/j.matdes.2010.08.014

[21] Balkevicius, V. and Pranckeviciene, J. (2008) Investigation of Properties of Composite Ceramics. Materials Science (Medžiagotyra), 14, 55-58.

[22] Maminski, M.Ł., Krol, M.E., Jaskołowski, W. and Borysiuk, P. (2011) Wood-Mineral Wool Hybrid Particleboards. European Journal of Wood and Wood Product, 69, 337-339. http://dx.doi.org/10.1007/s00107-010-0470-6

[23] Cochran, K. (2002) Estimation of the Generation and Composition of Construction and Demolition Debris in Florida. Master of Engineering Dissertation, University of Florida, Gainesville.

[24] Jeffrey, C. (2011) Construction and Demolition Waste Recycling-A Literature Review. Inhabitat 2011, Dalhousie University's Office of Sustainability.

[25] Yost, P.A. (1993) A Feasibility Study and Cost Analysis of Recycling Construction Site Gypsum Wallboard Waste. Master of Science Dissertation, University of New Hampshire, Durham.

[26] Townsend, T.G., Barnes, A.H., Cochran, K.M. and Carlson, J.J. (2001) Recycling of Discarded Gypsum Drywall in Florida. Final Report to The Florida Department of Environmental Protection. http://www.cdrecycling.org/assets/docs/State_Experience_PDFs/drywall2.pdf

[27] Ragab, N. (2014) Recycling of Waste Gypsum Boards to Produce New Drywalls and Non Load Bearing Bricks. Masters Dissertation, School of Sciences and Engineering, The American University in Cairo, Cairo.

[28] USEPA, US Environmental Protection Agency (1995) Construction and Demolition Waste Landfills Draft Report. Office of Solid Waste. ICF Incorporated Contract No. 68-W3-0008, 18 May 1995. 
[29] Horvath, A. (1999) Construction for Sustainable Development-A Research and Educational Agenda. University of California at Berkeley, Department of Civil Engineering, Berkeley. http://www.ce.berkeley.edu/ tommelein/CEMworkshop/Horvath.pdf

[30] Sjostrom, C. (1998) Sustainable Construction and Performance Based Standards and Codes. Centre of Built Environment. KTH Royal Institute of Technology, Stockholm. 